\title{
BUILDING LEVIATHAN: \\ REVENUE, STATE CAPACITY, AND GOVERNANCE ${ }^{1}$
}

\author{
Deborah Bräutigam
}

These are the rights which make the essence of sovereignty: ... The power to protect his subjects... [the power] of execution of the laws ... the power of raising money.

Thomas Hobbes, The Leviathan (1615)

\section{INTRODUCTION}

Raising revenue is the most basic task of the state. Before a state can protect its citizens, before it can provide justice or administer a bureaucracy, it needs to raise money. Through its key role as the tie that binds the ruler and the ruled, taxation supports representation, accountability, and state capacity. Yet taxation and revenue are rarely mentioned as democracy and governance issues in developing countries. ${ }^{2}$ A concern with taxation should be at the core of development efforts, yet it is not. ${ }^{3}$

This article focuses on revenue, state capacity, and governance. It offers an appreciation of the potency of revenue as a development issue, and one that should not be left to economists. Taxation is usually a government's major source of revenue, but revenue raising in most developing countries is broader than taxation alone. Public enterprises and royalties on natural resources frequently play a role. Foreign aid is a -- sometimes the -- major source of revenue in many low-income countries, and this has made state-building a different matter over the past half century than ever before in history.

Above all, taxation and revenue are issues of national power (Lamborn, 1983: 126). Mobilising resources is not simply a technical exercise, but involves overcoming domestic and sometimes 
international political opposition. Countries trying to improve their extractive capacity in the era of foreign aid also face a circumscribed set of "acceptable" policies that narrow their options.

The article begins with a brief review of revenue raising, representation, and state capacity in historical perspective. It then considers three political issues associated with taxation and revenue-raising: state capacity; aid dependence; and participatory budgeting. Throughout, I draw on the example of Mauritius, a small but successful Leviathan, to illustrate some of the political and institutional dynamics of revenue raising, but also to challenge some of the conventional wisdom on revenue policy and foreign aid.

\section{REVENUE, REPRESENTATION, AND STATE CAPACITY: SOME HISTORY}

It is often argued that in Europe, war was the primary cause of the growth of the modern nationstate. Hobbes foreshadowed this analysis in The Leviathan, when enumerating the rights and responsibilities of the sovereign: 'Ninthly, is annexed to the sovereignty the right of making war and peace with other nations and Commonwealths; that is to say, of judging when it is for the public good, and how great forces are to be assembled, armed, and paid for that end, and to levy money upon the subjects to defray the expenses thereof.' The need for revenues stimulated more efficient bureaucracies in some cases; in others, greater representation in governance. War and taxation are thus intimately linked in interpretations of European history. The sovereign levied money upon his or her subjects (generally, economic barons who passed much of the burden down through the feudal system) to pay for wars and imperialist expansion.

In England, those barons demanded a greater say in the running of the country and better protection of their property rights; by 1688 , they had both. 'The key to the story,' noted North and Thomas (1973: 149) in their interpretative economic history, 'was the inability of the Crown successfully to enlarge fiscal revenues'. Less than a hundred years later, the American colonies went to war with England over, inter alia, taxation without representation. For those raised in the Anglo-American tradition, the link between taxation and representation became a fundamental tenet of political development. Yet several things need to be noted about this interpretation. First, that link operated between economic elites and the sovereign. It was not 
primarily a case of peasants and ordinary citizens demanding a greater say in the disposition of their money. If economic elites are largely outside the fiscal net, as they are in many developing countries, taxation may not stimulate effective demands for power sharing from authoritarian rulers. Taxation has to bite directly to stimulate calls for political change. Second, the need for revenues also stimulated institutional changes that provided a more secure and efficient foundation for taxation. This second point is often taken for granted, but it may in fact be as critical for development as the possible link with representation.

\section{State Capacity and Taxation in Early Modern History}

In Europe, nation-building in an environment of intense military competition, and later, the global competition of imperialism, created the rising demand for revenue. In China during the same era, a decentralised but coherent and vast bureaucracy, employing magistrates selected in highly competitive national exams dating back to the Sui Dynasty (581-618 AD), efficiently collected annual land taxes from China's 90 million acres. ${ }^{4}$ China's long history of bureaucratic tax administration shows that efficient taxation existed before the rise of the nation-state, and that the stimulus of war is neither necessary, nor (quite probably) sufficient, for the development of bureaucratic capacity.

In fact, the more important lesson from the European experience may be the link between revenue-raising concerns and demands for institutional change. In England, more secure private property rights and a revenue bureaucracy were the result. In Spain, which had early access to gold, silver and other plunder from its conquest of much of the New World, incentives to develop an efficient system of property rights, domestic tax bureaucracy, or to stimulate more efficient domestic production were absent. Furthermore, to offset the instability of their external sources of revenue, Spain's monarchs borrowed from the new capital markets. ${ }^{5}$ In 1562, interest costs on these loans drained more than 25 percent of the annual budget, and Spanish rulers declared bankruptcy six times between 1557 and 1647 (North and Thomas, 1973: 129). Economic stagnation in Spain lasted for several centuries while England revolutionised first agriculture, and then industry. North and Thomas blame that stagnation in large part on the sources of Spanish revenues. A cycle of foreign loans and repeated bankruptcy; foreign plunder; 
and domestic reliance on revenues from sheep herding failed to stimulate secure property rights or a more efficient economy.

\section{Of Colonial Rule and Revenue}

Colonial rulers used a wide variety of instruments to raise revenue. Sometimes they dispensed with the taxation link and used forced labour (corvée) to create local infrastructure directly. In Sierra Leone and other colonies, the British imposed "hut taxes" to pay for the costs of controlling the hinterland. Hut taxes were more efficient than land taxes in a region where land was held communally and property rights over it could take many forms. Later in the colonial period, they established marketing boards to tax exports through control of prices paid to farmers. The colonial powers saw taxation as a powerful tool for forcing rural populations into the market economy and creating a near compulsion for subsistence farmers to labour seasonally on the commercial plantations established by Europeans.

Some colonial governments took over the revenue raising systems put in place by earlier rulers. In Southeast Asia, they used the same tax farming institutions established by Malay princes in the pre-colonial era. Tax farms gave local merchants (frequently, the Chinese, who were conveniently alien) a monopoly on the sale of certain items - salt was a popular choice. The merchant was required to turn over a certain amount of revenue. Surpluses above that amount could be accumulated. Many of Southeast Asia's wealthy Chinese capitalists gained their start as tax farmers (Brown, 1994). In Africa, tax farming was also practised, but generally through delegating tax collection to local "chiefs" who were frequently promoted into positions and given authority they would never have had under traditional rule. ${ }^{6}$

Other colonies raised revenues by issuing securities in international capital markets. The legislative debates in Mauritius are illuminating in this regard. In 1901, during a debate over the degree to which the local Council of Government (the legislative council) had the right to propose the repeal or reduction of certain taxes in the colony, the Surveyor General pointed out that the securities issued by Mauritius were "at the top of the list. Our 4 per cent. inscribed stock is worth $£ 113$, while that of Canada, which is surely a richer country than Mauritius, is only 
worth $£ 105$." The Surveyor General went on to explain that the higher value was due to the guarantee of the Imperial Government standing behind the securities, but one of the council members objected and pressed the issue:

"We all admit that in the last resort the Imperial Government is responsible; and of course if the Imperial Government is responsible it should have a control; but not to the extent that is claimed now. The control which is claimed now is nothing more or less than this: We shall do what we please but you will not have the right of expressing your views, except when we come to you for a vote. That is all. But you curtail our rights! We had the right before - it is not denied - of expressing our views upon the existing taxation. That is denied to us now. We cannot open our mouths - certainly that is curtailing our rights.

When the Governor pointed to a circular from London suggesting that the change in the prerogatives of Crown Colonies in general had resulted from problems in the West Indies that had required financial assistance from the Imperial Government, the member exclaimed:

It may be right as far as the West Indian Islands are concerned, but what financial assistance has been given to the Colony of Mauritius? I fail to see. If I understand aright the meaning of this sentence there have been grants, there have been doles given to the West Indian colonies, but here nothing of the kind. 'Financial assistance' means what? It means money actually given by the Imperial Government, but the Imperial Government has done nothing of the kind for Mauritius. .. When a debtor does not fulfill his engagements towards his creditors the creditors have a right to step in and to see more clearly into the administration of the affairs in which they have invested money. But this has never been the case of Mauritius. . Make any comments you like upon Mauritius, but do not say that Mauritius in some respect is similarly situated as the West Indian Islands. We are not in their position. We have always met our engagements, we have always striven to pay our creditors - and that is why we have such a good name in England and why our debentures are worth 13 per cent. premium. ${ }^{7}$ 
This passage highlights three things about revenue raising in the colonial period. First, it is clear that as early as 1901, some colonies were expected to raise some of their operating budget in the London capital markets through the sale of securities and debentures, although with the backing of the colonial power. At least in the case of Mauritius, this created a track record and a reputation in the international market, while at the same time fostering a sense of self-reliance and pride in being credit-worthy. Second, although the drain of resources was normally from the colony to the colonial power, this was not always the case. Financial aid - "there have been grants, there have been doles" - was sometimes given out to the colonies, suggesting that even in an earlier period, some administrations were not able to raise enough revenue to pay for the very limited governance imposed under colonial rule. Related, they then had to suffer greater controls over their affairs. But if a colony was able to manage its finances well, it had earned a voice in tax policy, or so the Mauritians argued. Third, at least in the case of Mauritius, at a very early period representation, revenue, and accountability were intertwined. The local council, comprised partly of elected members, expected to be able to influence local tax policy, in part because it had built a credible commitment to fiscal responsibility - symbolised by the premium on their international bonds.

\section{The End of Colonialism and the End of Local Taxes?}

As colonialism ended, some newly independent governments dismantled the colonial local taxation systems (Guyer, 1992: 43). In many of the weaker post-colonial countries, nationalist leaders relied on revenues paid directly by enclave mining interests, avoiding the need to foster the development of a local business class that was seen as either being too closely linked to the former colonial power (a "pariah" business class) or as a potential challenge to government authority and control. ${ }^{8}$ For several decades many countries maintained the marketing boards that had been established in the later years of colonialism, and the gap between higher world prices and the low prices paid to African farmers became an important of revenue. Taxation on civil service salaries (that were easily "captured") was also significant. But aside from the civil service and farmers producing for export, as Guyer noted, "neither the rich nor the poor in much of present day Africa (or more particularly Nigeria) are taxed anything remotely close to the proportions of their income and wealth that their counterparts in peasant and capitalist history 
have often been forced to pay"(45). ${ }^{9}$ To the extent this was true, it underscores not only the missing link between taxation and representation (Guyer's point) but the untapped potential for greater self-reliance in some of the newly independent (and soon to be aid dependent) nations.

\section{REVENUE, TAXATION, AND DEVELOPMENT}

In 1963, as one country after another emerged from colonial rule, economist Nicholas Kaldor wrote an article for the journal Foreign Affairs with a title that reflected that untapped potential: "Will Underdeveloped Countries Learn to Tax?" (Kaldor, 1963). He laid out a number of issues that remain highly salient. He warned about the dangers of aid dependence, urged countries to consider a variety of revenue sources (for example, taxes on land as well as income), and pointed out that revenue shortfalls in some developing countries - Latin America in particular -- were probably due to a failure to tax the wealthy effectively.

As Kaldor suspected, many underdeveloped countries did have trouble learning to tax. Political control by economic elites explained some of the problem. Some governments may have seen other sources of revenue, including foreign aid, as involving less effort than taxation. In addition, learning to tax in the age of the Washington Consensus meant that countries now have fewer choices of instruments. The recipe for taxation is the same, no matter what a country's stage of development: recommended low tariffs mean that indirect taxation has to shift to valueadded taxes. Income and corporate tax rates are to be low and the taxes broad-based. Taxes on land are not part of the Consensus, although, as Kaldor remarked (1963: 413), "the taxation of land can be a very potent engine of economic development." In their formative periods, Asia and Europe both relied heavily on the land tax. Yet today land taxes are widely seen as "politically impossible" (Guyer 1992) removing what might have been a progressive and effective revenue source.

\section{Taxation and State Capacity}


Studies of governance repeatedly point to revenue raising as the foundation of state capacity. Kaldor's 1963 analysis threw a spotlight on the link between state capacity and taxation: "No underdeveloped country has the manpower resources or the money to create a high-grade civil service overnight. But it is not sufficiently recognized that the revenue service is the 'point of entry'; if they concentrated on this, they would secure the means for the rest (417; emphasis added)."

Some countries did see the link quite clearly. Thailand, which was never colonised but faced the threat of both French and British expansionism, reacted in the late $19^{\text {th }}$ century by reorganising its tax system. The first reforms took place in 1873, establishing a central budget system. In 1890, King Rama V invited fiscal advisers from England to oversee the country's revenue and expenditure accounts (Akira 1989: 79). These early moves helped undergird the relatively high level of capacity in Thailand's economic ministries. Efforts to increase capacity were initiated by Thai rulers, who had diagnosed their own problems and sought the solution from available international experts.

In the early years of development assistance, economists assumed that countries would need time and assistance to increase their tax revenues. Nobel laureate Sir W. Arthur Lewis pointed out in the 1960s that:

However sharply one may reform the fiscal structure, it is not politically feasible to increase sharply the share of taxation in the national income over a period of time. Except in wartime, attempts to do this have always ended in strikes and riots, even in one-party states. Only a police state can take an extra one percent of national income every year. If one wishes to raise the tax rate from fifteen to twenty per cent, this is normally something to do gradually over ten to fifteen years. Indeed this is the crux of the argument for foreign aid. Any country can afford to tax itself twenty per cent and save eight per cent, but if it is to get there from a much lower level one must give it time (1969: 52; emphasis added). 
Have developing countries increased their tax rates? A quick look at the data (Table 1, based on World Bank data that is unfortunately quite incomplete) suggests that middle-income countries have indeed followed Lewis's advice about gradually increasing their tax revenues. Over two decades, middle-income countries have increased the percentage of GDP from tax revenue by 4 to 5 points. For low-income countries, however, tax revenue as a percentage of GDP has declined by almost 3 points on average.

Generalised poverty and continued low prices for commodity exports explain some of this decline, but the degree to which revenues have failed to increase in the poorest countries is still striking. As Lewis argued (above), the argument for foreign aid rested in part on the expectation that countries would use it to expand savings and investment (including in human capital) while slowly increasing their ability to sustain the extra expenditure themselves. Middle-income countries, on average, have been able to do this, but the poorer countries have not. The failure of revenue raising seems to be most acute in countries that receive large amounts of aid.

\begin{tabular}{|l|l|l|}
\hline \multicolumn{2}{|l|}{ Table 1: Tax Revenue as Percentage of Gross } \\
Domestic Product, Averages \\
\hline & $\begin{array}{l}\text { Average, 1972- } \\
1976\end{array}$ & $\begin{array}{l}\text { Average, 1995- } \\
1999\end{array}$ \\
\hline $\begin{array}{l}\text { Low income } \\
\text { countries }\end{array}$ & 17.0 & 14.3 \\
\hline Lower-middle & & \\
\hline
\end{tabular}




\begin{tabular}{|c|c|c|}
\hline $\begin{array}{l}\text { income } \\
\text { countries }\end{array}$ & 14.9 & 19.0 \\
\hline $\begin{array}{l}\text { Upper-middle } \\
\text { income } \\
\text { countries }\end{array}$ & 18.2 & 23.3 \\
\hline \multicolumn{3}{|c|}{$\begin{array}{l}\text { Data Source: World Bank World Development } \\
\text { Indicators, 2001. Tax revenue includes taxes on trade, } \\
\text { income, goods and services, profits and capital gains. } \\
\text { Only central government tax revenue is included. }\end{array}$} \\
\hline
\end{tabular}

\section{Aid Dependence and Taxation}

Poverty, a large agricultural sector, and relatively small trade sectors do impede the collection of taxes (Ghura, 1998). But in poor countries that receive large amounts of aid, could it be possible that the incentive structure is also at fault? In June 2001, the Tanzania Parliament passed the government's 2002/02 budget of \$US 1.9 billion. However, projected revenues left a very large deficit of $\$ 722$ million that the government expected would be financed by grants and external loans. This large gap between revenues and expenditures exists despite a high level of concern about the issue of aid dependence, expressed both by government and donors (Fjeldstad, 2001).

In surveying the issue, former World Bank chief economist Joseph Stiglitz has argued that "it may make sense for the government to treat foreign aid as a legitimate source of revenue, just like taxes, and balance the budget inclusive of foreign aid" (1998: 10). But foreign aid is not just like taxes. Aside from the fact that some aid comes as a loan and must be repaid (unlike taxes), there are three other important differences. First, large amounts of aid can undermine responsiveness of government to taxpayers, establishing relations of accountability between donors and governments, not between governments and citizens. ${ }^{10}$ Only when aid comes as a loan, and citizens understand that it must be repaid through their taxes, are the latter accountability links fostered. Second, aid may affect the legitimacy of the state and this could 
affect tax revenues, in a vicious circle. When citizens identify donors as responsible for improved roads or health clinics, they may be less likely to hold up their end of the citizengovernment bargain by paying their assessed taxes. Third, aid does not require governments to develop capacity. In fact, the system of aid thrives on governments that lack capacity, while creating incentives both for donor agency employees and host country employees to resist effective capacity-building. ${ }^{11}$ Taxation does require capacity, and as countries move down the scale from simple trade taxes to consumption and income taxes, the demands on capacity rise. This creates an effective stimulus, that donors' conditionality simply has not been able to provide.

It is not easy to break the incentives set up through the aid system. Zambia, one of Africa's most aid dependent countries, agreed to a cash budget in 1993 in an attempt to establish fiscal discipline (Bolnick, 1997). A long history of borrowing in order to finance expenditures led Zambia to a per capita external debt that was one of the highest in the world. Inflation had reached 191 percent in 1992. Bolnick notes that as the cash budget was being discussed, "the stakes were high because credibility was a key to reviving the economy and sustaining donor support (306; emphasis added)." Yet though donors were the primary audience for the cash budget, one of the side effects of the cash budget was to "spark active concern with tax revenues. .... Suddenly, the attitudes toward tax administration took an abrupt turn. . ... Creation of a new revenue authority to professionalize tax administration became a clarion call for the 1994 budget (318)." The cash budget stopped Zambians from pushing the costs of current spending onto future generations (through borrowing) and only then did the need to boost state capacity become quite clear. ${ }^{12}$

The case of Zambia presents a particularly clear example of way the relationship between tax effort, state capacity, and aid dependence can work in some cases. In Sub-Saharan Africa, the data suggests a mild, but negative, correlation between levels of tax effort, and levels of aid. Chart 1 graphs aid levels averaged over the 1990-1995 period, with tax effort indices averaged over the same period (Stotsky and WoldeMariam, 1997). ${ }^{13}$ The slope is gently negative, suggesting that aid might in fact be associated with lower tax effort. Further research, controlling for other factors, would be necessary to test this hypothesis. Higher levels of aid can 
in fact usefully substitute for tax effort for low-income countries. The challenge is: how to prevent aid from muffling the "clarion call" to gradually build - not weaken - an aid dependent state's own extractive capacity?

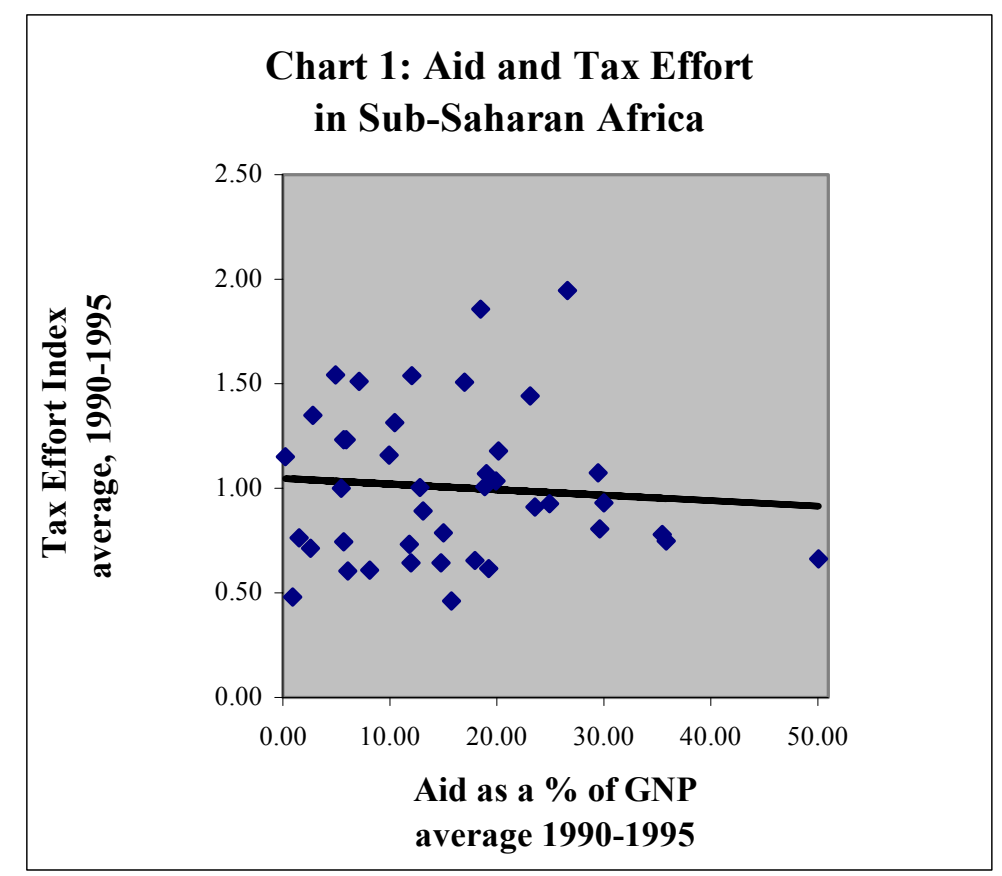

In fact, aid can be delivered in ways that support local ownership and at the same time reward productive effort. The European Union established one mechanism, through the Lomé Convention's special preferences for products produced in developing countries. These preferences have been rightly criticised for keeping countries locked into a pattern of raw material production. Yet Mauritius has benefited enormously from the Sugar Protocol preferences, which channels an estimated 3 to 7 percent of GDP to the country through the higher than market sugar prices. This source of foreign aid is largely ignored in studies of aid, but for countries like Mauritius, which invested in supporting the development of the privatelyowned industry while also levying a progressive tax on medium and large sugar producers in order to recoup some of this benefit, aid revenues through Sugar Protocol sales were "earned" income. With incentives from the government, the private sector in Mauritius channelled their sugar 'rents' into local export processing industries and tourism services. As Moore (1998 and 
2001) has pointed out, earned revenues are more likely to build accountability and foster a developmental state than revenues through natural resource mining or aid. They may also do more to promote the private sector, if accompanied by the right incentive framework.

Developing countries need to produce in order to procure the special preferences in the European market. This way of delivering aid resembles the "earned income tax credit" often touted in the United States as a way to boost incomes of the working poor. Unfortunately, the rise of WTO rules and the demise of special trading relationships mean that this source of "earned aid" is in the process of being eliminated.

\section{Participatory Budgeting and Better Governance}

Although the terms "taxation" and "revenue generation" are rarely heard in conjunction with democracy and governance in developing countries, budgeting issues are deeply political, and more participation in budget development may be an important mechanism for strengthening democracy and building a sense of accountability. It may also heighten understanding of the trade-offs in spending and revenue generation, possibly bolstering resistance to the risks of populist spending. In most of low-income Africa, citizens have little idea of the revenue/expenditure process. In Kenya before 1999, the budget process "was shrouded in mystery," as Achim Chiaji (2001) explains:

Technocrats at the Treasury monopolised the entire process of formulation and implementation of Kenya's Budget with disastrous consequences. The budget is not sufficiently debated before presentation and non-state participation results in too many donor-generated proposals. There has been considerable concern following revelations that the donor organisations led by the IMF are playing a major role in determining the 2001/2002 Budget proposals. Another weakness is that budget debate is neither integrated nor systematic hence it is often inexhaustive. Parliamentarians see the proposals for the first time when the Minister for Finance presents it for debate in parliament. The period allowed for debate is also too short considering the fact that the report is usually broad and over 400 pages. Furthermore, the budget is crafted in a 
technical language that makes it difficult for ordinary wananchi to interpret its real implications.

Contrast this with Mauritius. In the late 1970s, Mauritius lurched through a series of economic crises that were only ended when the country managed to devalue the rupee (twice), cut spending, and attract investment into the export-processing zone. As part of the political handling of the crisis, the government began to consult more openly with the main "social partners" on economic and social policy, and, in particular, on the budget. Over the past two decades, those consultations have become deeply institutionalised. Each year in the spring, the Minister of Finance makes the rounds of the country's major stakeholders, listening to their views, exchanging comments, accepting their written analyses. Each evening, the television news is full of brief reports of these consultations: union members meet the Minister one day; business associations another; and the major social welfare NGOs and other associations also have their opportunity. When the budget is finally presented to Parliament, the details are splashed across the major newspapers. Almost instantly (since 1996/97), the budget speech and the entire budget are accessible on the Internet. All donor funding is channelled through the budget, with details linking funding sources to particular development expenditures. Aid is fully transparent, and borrowings are publicised.

Participatory budgeting and a visible link between taxation and spending in Mauritius forced groups outside the government to enhance their own capacity, in order to interact with the government as credible peers, and gain an audience for their analyses. It also allows Mauritians to challenge their government through their lively press, as happened not long ago with the Minister of Education concerning a proposed education project. An open letter in the country's major newspaper pointed out that the project was flawed, and reminded the Minister: "If the government borrows millions of rupees from the World Bank for your project, it is done in the name of All the Mauritian people ... If it is necessary to repay this debt of millions of rupees for a project, it is each one of us ... who are going to pay by our taxes." ${ }^{\prime 14}$ The link between taxation, revenue, and accountability is quite clear. 
This link needs to be stronger in many low-income countries. What is the potential for change? In some countries (now including Kenya), the new emphasis of the World Bank and the International Monetary Fund on civil society consultation over Poverty Reduction Strategy Papers (PRSPs) has in effect created consultations over the budget. In Africa, Uganda was the first HIPC ${ }^{15}$ country to try participatory budgeting. The Ministry of Finance began to consult the country's major social groups in the process of preparing the country's first Poverty Eradication Action Plan (PEAP, which later became the PRSP) in order to qualify for debt relief from the World Bank and the IMF. Also with donor encouragement, Uganda adopted a three-year, medium-term budget framework that emphasises civil society involvement. Although making budgeting more transparent and participatory holds potential for increasing accountability in Uganda, the civil society discussion focuses almost entirely on the expenditure side ("dividing the cake"); there is little discussion of the revenue side, except for uses of donor funds. ${ }^{16}$ Since civil society organisations are usually tax-exempt, this means that the political link between taxpayers and government spending is still missing. ${ }^{17}$ The process is also largely donor-driven, and it is not clear how deeply it will be institutionalised before the donors step out of the picture. Unlike many other donor "fads" however, this process stimulates a felt need for greater capacity in many branches of government hitherto outside of the budgeting process, and in civil society. It does not require foreign technical assistance, and it emphasises accountability through active citizen monitoring. However, it does depend on a close correlation between the budget and actual expenditures, something that has been difficult to achieve in aid dependent countries, where, among other problems, the gap between commitments and disbursements can be quite large (Brautigam 2000; Burnell 2001).

\section{FINAL THOUGHTS}

"The power of raising money" is central to sovereignty, Hobbes argued. It may also be central to the process of political development. Historically, the need to raise revenues led to institutional change: more efficient property rights, more effective bureaucracies. Today, a certain degree of extractive capacity may be a prerequisite for state capacity and "ownership" of development strategies. 
Taxation may also stimulate representation and greater accountability - although this is unlikely to happen unless political and economic elites themselves feel the bite of tax policy directly. The "Boston Tea Party" protest was led by New England merchants whose business interests were threatened by changes in tea duties. The understanding that revenue, representation, and accountability are linked was loudly expressed in the Legislative Council in Mauritius more than 100 years ago, but along with the emphasis on voice, was the expectation that accountability was a two-way street. Responsible fiscal behaviour had earned the Legislative Council the right to demand a greater say in tax policy. Mauritians still make the connection between accountability and taxation, demanding that the government spend their tax dollars wisely, even if foreign aid is involved. In many other countries that link between citizens and governments is broken. Efforts to repair it by promoting participatory budgeting may have some impact, particularly if they stimulate greater capacity building among non-governmental organisations. Yet unless all donors agree to program their aid only through the budget, and step back from dictating budget proposals, participatory budgeting will be a hollow exercise.

Learning to tax, as Nicholas Kaldor pointed out, 'does not depend merely on the individual good will of ministers or on the correct intellectual appreciation of the technical problems involved. It is predominantly a matter of political power (1963: 418; emphasis added).' Countries like Mauritius learned how to tax long ago and over time, built a 'virtuous circle' weaving together taxation, capacity, representation, and accountability. We in the development studies community clearly need to pay more attention to the specific ways in which foreign aid can help states and societies build these links rather than try, feebly, to substitute for them. 


\section{REFERENCES}

Akira, Suehiro. Capital Accumulation in Thailand Tokyo: The Centre for East Asian Cultural Studies, 1989.

Bolnick, Bruce R. "Establishing Fiscal Discipline: The Cash Budget in Zambia," in Merilee S. Grindle, ed. Getting Good Government: Capacity Building in the Public Sectors of Developing Countries (Cambridge, MA: Harvard Institute for International Development, 1997), pp. 297-331.

Bräutigam, Deborah. Aid Dependence and Governance Swedish Ministry of Foreign Affairs, Expert Group on Development Issues Report 2000:1. Stockholm: Almqvist \& Wiksell International, 2000.

Brown, Rajeswary Ampalavanar. Capital and Entrepreneurship in South-East Asia, London: St. Martin's Press, 1994.

Burnell, Peter. 'Financial Indiscipline in Zambia's Third Republic: the Role of Parliamentary Scrutiny,' Journal of Legislative Studies v. 7, n. 3, 2001: 34-64.

Cartwright, John R. Political Leadership in Sierra Leone Toronto: University of Toronto Press, 1978.

Chiaji, Achim. 'A Poverty-focused budget process: Challenges, Obstacles and Opportunities,' EcoNews Africa (May/June 2001). http://www.econewsafrica.org/budgetmayjune.html Accessed March 1, 2002.

Fjeldstad, Odd-Helge. 'Taxation, coercion and donors: local government tax enforcement in Tanzania,' The Journal of Modern African Studies 39, no. 2 (2001): 289-306

Ghura, Dhaneshwar. 'Tax Revenue in Sub-Saharan Africa: Effects of Economic Policies and Corruption.' International Monetary Fund Working Paper: WP/98/135. (September 1998).

Guyer, Jane. 'Representation without Taxation: An Essay on Democracy in Rural Nigeria, 19521990,' African Studies Review v. 35, n. 1 (April 1992).

Hirschmann, David. 'Aid Dependence, Sustainability, and Technical Assistance: Designing a Monitoring and Evaluation System in Tanzania,' International Development Program, School of International Service, American University, Washington, DC, 2002 (draft).

Kaldor, Nicolas, 'Will Underdeveloped Countries Learn To Tax?' Foreign Affairs v. 41 (January 1963): 410-19. 
Lamborn, Alan C., 'Power and the Politics of Extraction,' International Studies Quarterly 27 (June 1983).

Lewis, Arthur. Some Aspects of Economic Development Tema: Ghana Publishing Corporation, 1969.

Migdal, Joel. Strong Societies and Weak States: State-Society Relations and State Capabilities in the Third World Princeton University Press, 1988.

Moore, Mick. 'Death Without Taxes' in Mark Robinson and Gordon White, eds. The Democratic Developmental State: Politics and Institutional Design Oxford: Oxford University Press, 1988.

Moore, Mick. 'Political Underdevelopment; What Causes ‘Bad Governance’? Public Management Review, 3(3), 2001.

North, Douglass C. and Robert Paul Thomas, The Rise of the Western World: A New Economic History New York: Cambridge University Press, 1973.

Rakner, Lise, Nicolas van de Walle, and Dominic Mulaisho, 'Zambia,' in Shantayanan Devarajan, David R. Dollar, and Torgny Holmgren, Aid and Reform in Africa: Lessons From Ten Case Studies Washington, DC: The World Bank, 2001.

Spence, Jonathan. Emperor of China: Self Portrait of K`ang Hsi. New York, Vintage Books, 1975 .

Stiglitz, Joseph, 'More Instruments and Broader Goals: Moving Toward the Post-Washington Consensus,' WIDER Annual Lectures, 2, (Helsinki: UNU/WIDER, 1998).

Stotsky J. G. and A. WoldeMariam (1997) ‘Tax Effort in Sub-Saharan Africa,' International Monetary Fund Working Paper WP/97/107, Washington, D.C., IMF (September).

World Bank. World Development Indicators 2001 (CD-rom) Washington, DC: The World Bank, 2001. 


\section{NOTES}

${ }^{1}$ Many thanks to the Woodrow Wilson International Center for Scholars for a resident fellowship 2001-2002, during which this article was written. Research assistants Sylvia Kim, and especially Grissel Mercado, have been very helpful in some of the background work for this article. Thanks also to David Kinsella for technical assistance, and to David Hirschmann, Lise Rakner, and Mick Moore for careful reads and helpful comments.

${ }^{2}$ For exceptions, see Guyer (1992) and Moore (1998 and 2001).

${ }^{3}$ For example, a recent search of the World Bank's project database brought up 44 projects concerned with "tax" or "taxation", but 402 related to "trade".

http://www.worldbank.org/sprojects (Projects search engine). Accessed February 26, 2002.

${ }^{4}$ Spence (1974: xvi); Thanks also to Zhou Yongming and Chris Reardon for discussions on China's tax bureaucracy.

${ }^{5}$ Why did England not do this? I don't know, but it's an important and interesting question.

${ }^{6}$ It would be interesting to know the extent to which these chiefs were able to accumulate wealth through their control over indirect taxation, and whether or not, if they did, they invested in trade or production, as did their counterparts in Southeast Asia.

${ }^{7}$ Mauritius Council of Government, 1902: 447-453, passim.

${ }^{8}$ Cartwright (1978: 252) cited in Migdal: 266.

${ }^{9}$ Guyer's research suggested that European peasants in the Middle Ages paid about a third of their harvest in taxes (p. 72, n. 9).

${ }^{10}$ See Moore (1998 and 2001) for an excellent expanded treatment of this problem.

${ }^{11}$ For an example of how this works in practice, see Hirschmann (2002). 
${ }^{12}$ Unfortunately, as Rakner et al (2001) have demonstrated, the constraint of the cash budget failed to rein in expenditures; it simply meant that suppliers were not paid.

${ }^{13}$ Date on aid comes from the World Bank (2001). Data on tax effort comes from Stotsky and WoldeMariam (1997) who develop their tax effort indices using not the standard measure which is simply tax revenue as a percentage of GNP, but a measure that reflects the structure of the economy and the possible sources of revenue. The chart omits the outlier country of São Tomé and Principe, which had an average aid dependence of 115.55 percent of GNP, and an aid effort of 0.74 (1.00 is average; 0.74 is well below average). Including São Tomé and Principe makes the regression line steeper.

14 “Lettre Ouverte à M. le Ministre de l'Education et à ses Conseillers," Le Mauricien (Port Louis), 14 April, 1999, p. 11 (my translation).

${ }^{15}$ HIPC is the Highly Indebted Poor Country multilateral debt relief initiative.

${ }^{16}$ For example, the World Bank notes that: "Under the Medium Term Budget Framework, line ministries are provided global budgetary ceilings on which to base their sectoral allocations. New sectoral working groups comprising the Ministry of Finance, line ministries, and technical advisors were established to help develop sectoral priorities within the expenditure limits. For the first time, civil society is involved in the dialogue on priorities and spending commitments. To better reflect district poverty priorities and to bring local governments into the medium-term expenditure process, local government officials also prepare medium-term expenditure plans. This process feeds into the budget framework paper and annual budgets." World Bank, "Uganda: Poverty Reduction Strategy" (no date) Accessed February 28, 2002.

http://www.worldbank.org/poverty/strategies/uganda.htm.

${ }^{17}$ Furthermore, of the many documents that exist describing Uganda's participatory budgeting, 
few bring in the role of parliament, normally one of the major vehicles through which democratic participation happens. 